\title{
GOOD GOVERNANCE, GENDER MAINSTREAMING, AND RELIGION
}

\author{
By: M. Roem Syibly ${ }^{*}$
}

\section{Abstract}

From Good Governance perspective, Indonesia has given positive contribution toward gender issues. Legally, Indonesia has fulfilled all conditions as state with good governance, but unfortunately, at the field showed that such ordinances issued were ineffective. PSI-UII's research report has found the correlation between violence against women and religious understanding. In the field finding will give inputs to all people who concern with the issue. Several Muslim scholars already had given us some solution with interpretation toward al-Quran and Hadits, which support gender justice and equality. Government and all organization involved, have to support law and its instrument can be applied well.

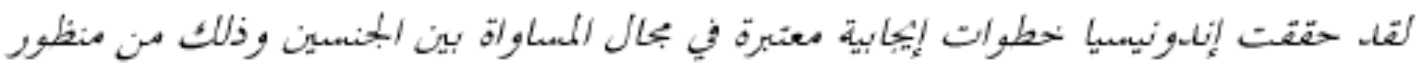

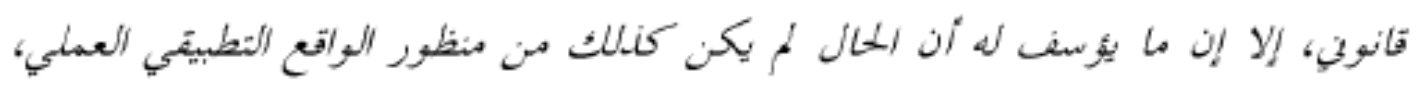

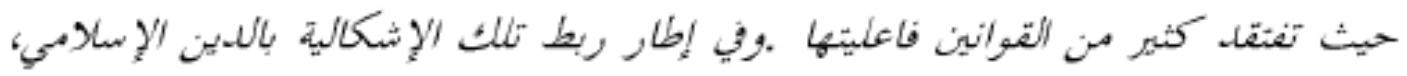

$$
\begin{aligned}
& \text { توصل الباحث إلى أنه لا توجاه أي علاقة تنكر بين العنف الموجه نحو المرأة والمغاهيم } \\
& \text { ألدينية .يطمح الباحث أن توفر نتائج البحث الحقلية فرصة للوعي بالمساواة بين الجنمسين }
\end{aligned}
$$

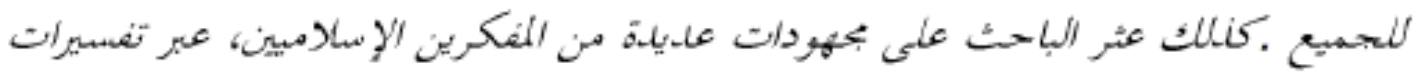

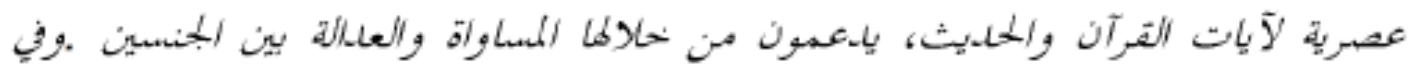

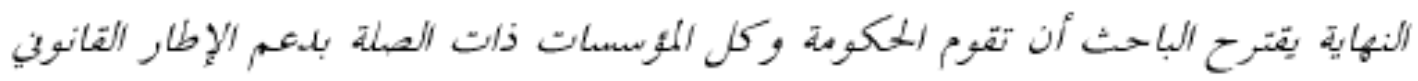

$$
\begin{aligned}
& \text { وبّبيق أدواته في هانا السيات . }
\end{aligned}
$$

Keywords: governance, gender, religious interpretation.

\section{A. Introduction}

In spite of the frequent mention of the term "Good Governance" (Ind.: tata kelola yang baik) is made, it may imply various meanings. In general, it means "pengelolaan pemerintah yang baik" (good governance of government). The term 
"baik" (good) here means "following the regulated rules as set out in the principles of good governance." In this article, I prefer to follow UNDP's concept of good governance which is defined as the use of economic, politic, and administrative policies to manage governmental matters at all levels. Government administration includes all mechanisms, processes and institutions, through which citizens and mass groups express their interests, enjoy their legal rights, observe their duties and fill their gaps.

Good government administration bears the following characteristics:

1. Involving all related components;

2. Transparent and responsible;

3. Effective and just;

4. Guaranteeing law supremacy;

5. Guaranteeing that political, social and economic priorities based on mass consensus;

6. Paying attention to the interest of the poor in policy making processes concerning the allocation of development fund resources. ${ }^{2}$

In this article, I will focus on the gender positioning in ideal governance. This is due to the fact that so far the gender positioning has been marginalized. The questions to be answered here are: have the existing governance accommodated gender perspective? Is there already justice for gender? Have women's interests been accommodated in policy making process? This article seeks to describe how gender can be placed and empowered in development and how religion can contribute to it.

As reported by Komnas Perempuan (National Committee for Women) 2003, the number of domestic violence increased $45 \%$ compared to that before. As many 14,020 of 20,291 cases were dealt with in 215 institutions in 29 provinces, including Special Province of Yogyakarta. Data by Komisi Nasional Anti Kekerasan Terhadap Perempuan (National Committee of Anti-Violence against Women) shows that in 2003 there had been 5,934 cases concerning violence against women. From 2,703 
cases of KDRT (domestic violence) $75 \%$ of them were wives. Even in 2005, the number of cases was $16,000 .^{4}$

Appeals, statements and planned actions had been made to enhance the social condition life. Majelis Ulama Indonesia, on all forms of publication and broadcasting, displaying pictures, visual, program and news on pornography in the mass media, either electronic or printed, as that of fatwa of the Central Board of Nahdlatul Ulama, has also issued a fatwa on infotainment prohibition ${ }^{5}$.

\section{B. Development and Gender Empowerment}

From the historical perspective, gender participation and empowerment has emerged since about 1908, when the national awakening movement was going on. At the time, Indonesian women took an important part, even in a limited scope. In the declaration of "Sumpah Pemuda" in 1928 was stated "Pemuda dan Pemudi Indonesia" (Indonesian men and women youth). On 22 December 1928, Women Congress I was held as the manifestation of women participation in independence movement. The moment is annually commemorated as the "Day of Mother" (Hari Ibu). Cut Nya' Dien, Keumalahayati, Martha Tiahahoe, and Yolanda Maramis were among Indonesian women who took a part in independence struggles. ${ }^{6}$ Since 1978 , the special ministry for women has been established, previously Youth Ministry of Women Participation and currently Ministry of Women Empowerment.

International record on gender development and empowerment can be found in the Declaration of Human Rights, the United Nations (UN) in 1948. The declaration inspired the rise of feminist movements in the struggle for women rights. It was stated that "all human beings are born free and equal in dignity and rights". In 1952, the UN adopted women political and economic rights. In 1963, global emancipation movement became the agenda of the UN (Ecosoc). The Commission on the Status of Women 1967 inspired the emergence of PKK (Pembina Keluarga Sejahtera, Guide of Family Welfare). ${ }^{7}$ In a conference in Mexico in 1975, WID (Women in Development) was set up as a strategy to develop the role of women. A conference in Nairobi in 
1985 made a agreement on the establishment of UNIFEM, the UN organization for women) with the programme of WAD (Women and Development). In 1979, CEDAW-UN was held and Indonesia ratified.

A meeting in Vienna in 1990 agreed on the programme of GAD (Gender and development). Indonesia ratified GAD through Presidential Decree No. 36 Year 1990 with gender mainstreaming strategy. ICPD Conference, Cairo, 1994, set an agenda of protecting reproduction rights of women in a sustainable development. In 1995, Beijing Conference was held.

CEDAW, BPFA, and MDG's (Millenium Development Goals) are a number of international policies to reduce discrimination against women. CEDAW (Convention on the Elimination of All Forms of Discrimination Against Women), was signed by the government on 29 July 1980 and ratified into UU RI No.7 Year 84 about the legislation of CEDAW. It much focused on the way to overcome discriminations against women. ${ }^{8}$ BDFA (Beijing Declaration and Platform for Action) was held on the basis of the recommendation of the World Conference on Women IV, 4-15 September 1995. It was more concerned with the strategy to cope with 12 critical regions in the framework of the empowerment of women in the UN members. ${ }^{9}$ MDG's, ${ }^{10}$ declared on 10 September 2000, was focused on the role of women in 2015.

Based on three programmes above, Indonesia has produced a number of regulations to regulate and give legal certainty to gender development and empowerment. They are:

1. UU (Act) No.18 Year 1956 about Women Political Rights Convention;

2. UU No. 1 Year 1974 about Marriage, and PP (Regulation) No. 9 Year 1975 about the Implementation of UU No 1 Year1974;

3. UU No. 23 Year 2002 about Children Protection;

4. UU No. 23 Year 2004 about Eradication of Domestic Violence;

5. UU No. 25 Year 2004 about Planning System of National Development; 
6. PP No. 4 Year 2006 about the Organizing and Cooperation for Recovery of Victims of Domestic Violence;

7. Keppres (Presidential Decree) No. 59 Year 2002 about National Action Plan for Eradication of Bentuk-Bentuk Pekerjaan Terburuk untuk Anak;

8. Keppres No. 87 Year 2002 about National Action Plan for Eradication of Children's Commercial Sexual Exploitation;

9. Keppres No. 88 Year 2002 about Planning for National Action of Eradication of Women and Children Trafficking;

10. Keppres No. 77 Year 2003 about Indonesian Committee for Children Protection;

11. Keppres No. 40 Year 2004 about Planning for National Action of Human Rights Indonesia 2004-2009;

12. Keppres No. 52 Year 2004 about National Committee for Lanjut Usia;

13. Keppres No. 106 Year 2004 about Tim Koordinasi Pemulangan Tenaga Kerja Indonesia Bermasalah dan Keluarganya dari Malaysia;

14. Inpres No. 9 Year 2000 about Gender Mainstreaming in National Development;

15. Joint Decree of State Minister of Women Empowerment, Minister of Internal Affairs, and Minister of National Education No. 17/Men.PP/Dep.II/VII/2005, No. 28A TAHUN 2005, No. 1/PB/2005 about Acceleration of the Eradication of Women's Illiteracy;

16. Decree of Minister of Internal Affairs No. 132 Year 2003 about General Guide of the Implementation of Gender Mainstreaming;

17. Standard for Minimum Service of Women Empowerment in Regions (Based on SK Meneg PP No. 23/SK/MENEG/PP/21.

A number of regulations become basis for gender empowerment and development. They are: District Government (UU No. 32 Year 2004 about District Government in place of UU No 22 Year 1999; UU No 34 Year 2004 about Financial Balance between Central Government and District Government in place of UU 25 Year 1999; and PP No. 25 Year 2000 about Governmental Authority and the Authority of Province as Autonomic Region). ${ }^{11}$ 
In “Temu Nasional Aktivis Perempuan Indonesia,” Jakarta, 28-31 August 2006, were set up agendas of education, politic, sexuality, natural resources, law, fundamentalism, globalisation, poverty, technology, media, culture and disaster. In addition, gender issues in the context of regional autonomy came to the fore as well. ${ }^{12}$

The above description shows that attempts to cope with violence against women in both national and international levels have been made. However, in general the result is still beyond the hope. NGOs concerned with this issue also have given consultation and information to society, but the number of violence against women seems not to decrease.

A number of regulations newly produced even are contra-productive. For instance is regulation on discrimination. In 2006 Komnas Perempuan reported that 26 new regulations produced in 16 regions (including provinces, regents, and villages) tend to be discriminative against women. These regulations include Perda (Regional Regulation), Surat Edaran, Surat Keputusan (Policy Letter) of bupati, and so forth.

Material testing mechanism through Mahkamah Agung (Supreme Court) did not totally eliminate discrimination against women as stated in UU No. 7/1984. This contradicts article 2 of CEDAW Convention which states that country members must make sure the implementation of regulations to protect women from discrimination. This article also emphasizes that they must guarantee equality before the law for women. ${ }^{13}$

\section{Religious Relation, Gender, and Development}

Religion is often considered one of the crucial factors which engendered injustice and inequality towards women. ${ }^{14}$ Responses of religious communities to violence, insult, and discrimination against women stimulated the rise of religious feminist movements. ${ }^{15}$ These movements provoked controversies since they based their ideas on the awareness of women oppression. ${ }^{16}$

It has become altruism that religious doctrine is always just and pays high respect to gender equality. However, its interpretation is often distorted by patriarchal 
tendencies among Muslim societies. ${ }^{17}$ there is always a gap and even clash between text and context, theory and practice. It is therefore necessary to explicate the interrelation of religion and gender in development. Development and gender empowerment are rooted in religious ${ }^{18}$ and cultural ${ }^{19}$ values. Every religion has its own concept of human and especially women. From the concept, we should understand the relation of gender and religious values, and reinterpret the essence of the creation of women. ${ }^{20}$

A research by Pusat Studi Islam (Centre for Islamic Studies) UII, in cooperation with CORDAID, ${ }^{21}$ has proved that mass people have frequently justified violence against women in the name of religion. The research reported that for them having sons is better (than having daughter). Although some people condemn polygamy, unofficial practices of polygamy are commonly considered being religiously legal. Thus, most people tend to opposite gender equality, and therefore, they do injustice to women.

Family and marriage relation should create cooperation between husbands, wives, and other members of family. This is in contrast to the opinion that women are always the victims of marriage institution and family. This opinion emerges from religious misinterpretation. Therefore, there should be an attempt to contextualize religious texts. ${ }^{22}$ Gender studies of religions emphasize gender justice and equality as counter critic against those who justified injustice and inequality of women. Gender biased understanding and interpretation are the result of patriarchal social system. In this system, religious interpretations often play a decisive role in enduring the oppression of women. Such interpretations tend to claim to be the most authoritative since they use religious texts as their basis. As a result, different interpretations can easily be seen as subversion. ${ }^{23}$

Alternative exegetical enterprises have been offered by a number of Muslim scholars such as Qasim Amin, Riffat Hassan, and the like. Qasim Amin maintains that oppression against women does not emerge from the Quran and the hadith. Conversely, it is because the position of women is often seen as a threat to men's 
position. ${ }^{24}$ From historical and comparative analysis, Amin concludes that the oppression of women is in contradiction to Islam. Similarly, Riffat Hasan formulates her conception of women's position from Islamic monotheism. She said that "truly monotheistic beliefs such as Islam will never let human worship except God. Thus, over-submission of women to their husbands is irrational." 25

\section{Conclusion}

The government has made legal-formal attempts concerning gender equality. However, the attempts lack in law enforcement. On the other hands, NGOs' attempts at giving counselling were not accompanied with knowledge of the roots of the problems. The findings of the research by PSI-UII clearly show that distorted religious understandings have played a significant role in this matter so that violence against women is often supported by religious interpretations.

What should be done in this regard is to create religious interpretations which provide Muslims with the way out of violence against women and a fair gender conception. This can be materialised by involving relevant institutions such as Kantor Urusan Agama (KUA), Pengadilan Agama (religious court), Pengadilan Negeri (State court) and others, as well as religious leaders and Muslim societies. By doing so, the institutions can contribute significantly to the creation of good governance.

\footnotetext{
*Researcher at Pusat Studi Islam (PSI) UII, and member of the researchers team within the programme of Sikap Kesetaraan Gender dalam Keluarga Lintas Agama (Attitude towards Gender Equality in Inter-religious Families, in the framework of cooperation between PSI and CORDAID 2006-2007.

${ }^{1}$ On Good Governance, see http://www.transparansi.or.id. (Accessed 29 July 2007).

2 See, Tata Pemerintahan Menunjang Pembangunan Manusia Berkelanjutan, in Bulletin Partnership for Governance Reform in Indonesia Volume IV - June 12, 2000. Also see Beberapa Pemikiran Tentang Good Governance, in http://www.goodgovernance-bappenas.go.id. (dikutip pada 26 Juli 2007).

3 Catatan Tahunan tentang Kekerasan Terhadap Perempuan, Komnas Perempuan, 8 Maret 2006, in http://www.komnasperempuan.or.id. (accessed on 22 September 2006).

4 Melani (2006), "Kartini Melawan Kekerasan Dalam Rumah Tangga”, in Pikiran Rakyat, 4 February 2006.
} 
5 "MUI Kecam Pornografi di Media Massa," in Kompas, 19 February 2002; See also, "MUI Dukung Polri Berantas Pornografi," Kompas, 26 March 2002. On the controversy against "infotainment," see Zuhairi Misrawi, "NU, 'Infotainment,' dan Sikap Moderat," Kompas, 12 August 2006; See also, Sunardian Wirodono, "Fatwa Haram Infotainment, Halalkah?", Kedaulatan Rakyat, 22 August 2006; also Mohammad Najib, "Fatwa Haram Infotainment," Kedaulatan Rakyat, 26 August 2006.

6 See mailing-list "sastra pembebasan"<sastra-pembebasan@yahoogroups.com> [indomarxist] Rusiyati [Dokumen Tercecer]: "Sepintas Gerakan Wanita Indonesia Dalam Perkembangan Sejarah," (1-5), Thu, 21 Sep 2006 07:31:46 -0700 (PDT); Fri, 22 Sep 2006 03:54:52 -0700 (PDT); Sat, 23 Sep 2006 15:10:49 -0700 (PDT); Sun, 24 Sep 2006 16:49:05 -0700 (PDT); Mon, 25 Sep 2006 14:44:29-0700 (PDT). Dokumen ini dipresentasikan pada pertemuan peringatan Hari Kebangkitan Perempuan Indonesia, 22 Desember 1990, di Amsterdam, Belanda.

7 PKK stands for Pembinaan Kesejahteraan Keluarga (Guidance for Family's Welfare). This programme is financially supported by APBN and APBD at provincial and regent levels. Later on, PKK stands for Pemberdayaan Kesejahteraan Keluarga (Empowerment of Family's Welfare).

8 Basic data and report of CEDAW can be found in http://www.un.org/womenwatch/daw/cedaw/. For Indonesian, see Pelaksanaan Konvensi CEDAW di Indonesia, Edisi II No.3 July-September 2005, http://www.kalyanamitra.or.id. (accessed 22 September 2006).

9 On the basic data and report of the implementation of BPFA, see http://www.aworc.org/bpfa/res/bpfa-tool.htm.

10 Eight points on Tujuan Pembangunan Milenium (Goal of Millennium Development) are poverty elimination, education for all, gender equality, struggle against diseases, decreasing of baby mortal rate, improving mothers' health, conservation of environment, and global cooperation. Basic data and report of MDGs can be seen at http://www.un.org/millenniumgoals/, www.developmentgoals.org. On the gender development and MDGs, see www.mdgender.net. See also www.urbanpoor.or.id, www.gelangputih.org, www.infid.org.

11 Membangun Otonomi Daerah bagi Semua, Kompas, 16 October 2006.

12 Manifesto Temu Nasional Aktivis Perempuan Se-Indonesia, 05 September 2006, dalam http://www.prakarsa-rakyat.org/artikel/urgent/artikel.php?aid=11643, (accessed 22 September 2006).

13 Press conference on Independent Report of Komnas Perempuan to CEDAW committee 19 Juli 2007, Mempersoalkan Tanggung Jawab Negara atas Munculnya Kebijakan-kebijakan Diskriminatif bagi Perempuan, dalam http://www.komnasperempuan.or.id/ dikutip pada 29 Juli 2007.

14 M. Fakih (1995), Menggeser Konsep Gender dan Transformasi Sosial, Yogyakarta: Pustaka Pelajar, pp. 11-20.

15 representative of Christian feminists are Elizabeth Fiorenza, Yudith Plaskow, and Rosemary Redford Ruether; including men, religious leaders and clerics. For Indonesian cases, see Pdt. Ioanes Rakhmat, Ciri-Ciri Fundamentalisme Kristen Dewasa Ini, in http://www.sttjakarta.ac.id/umum_artikel/051015_ioanes_ciri-cirifundamentalisme.htm, (accessed on 22 September 2006). In Islam, Rifaat Hasan, Fatimah Mernissi, and Amina Wadud are the prominent figures. See Siti Ruhaini Dzuhayatin, "Pergulatan Pemikiran Feminis dalam Wacana Islam di Indonesia," in Ema Marhumah and Lathiful Khuluq (2002), Rekonstruksi Metodologis Wacana Kesetaraan Gender dalam Islam, Yogyakarta: Kerjasama PSW IAIN Sunan Kalijaga, McGill-ICIHEP dan Pustaka Pelajar, 2002, pp. 3-5.

16 Telaah terhadap feminisme merujuk pada "Feminisme," dalam http://id.wikipedia.org. (dikutip pada 16 Oktober 2006).

17 Sakdiyah Makruf, Bukan Semata-mata Tuntutan Perempuan, dalam http://islamlib.com (dikutip pada 16 Oktober 2006). 
18 Elisabeth Schussler Florenza (1988), In Memory of Her (A Feminist Theological Reconstruction of Christian Origins). London: SCM Press Ltd.

19 See Ursula King (1986), Female Identity and The History of Religions, dalam Victor C. Hayes (ed.). Identity Issues and World Religions, Netley S.A: Wakefield Press, pp. 83-91.

20 Alef Theria Wasim (1995), "Sosialisasi Wawasan Gender dan Pembangunan. dalam AlJami’ah”, Jurnal Ilmu Pengetahuan Agama Islam, No. 58 Th. 1995, p. 38.

21 Research by PSI-UII in cooperation with CORDAID in the programme of Sikap Kesetaraan Gender di dalam Keluarga Lintas Agama di DIY, November 2006 - Maret 2007.

22 Asma Barlas (2005), Cara Quran Membebaskan Perempuan, trans. R. Cecep Lukman. Jakarta: Serambi, pp. 291-294.

23 A number of examples can be given here. Aminah Wadud led a Friday prayer in an Anglikan church in America in 2005. Fatima Mernisi re-examined misogynist issues in the Muhammadan narratives in her Women and Islam, 1991; Josef P Widyatmadja campaigned against WTO in Victoria Park, 13-18 December 2005, Hongkong with a theme God, Food, and WTO. A survey "Survei Nasional: Dukungan dan Penolakan Terhadap Radikalisme Islam," LSI, 16 March 2005, provoked public controversies.

24 Qasim Amin, Al-Mar'ah al-Jadidah (Kairo: al-Markaz al-Arabiyah, 1984). The book is part of a series of Tahrir al-Mar'ah (Pembebasan Perempuan).

25 Riffat Hasan, An Islamic Perspective, Women, Religion and Sexuality. Ed. Jeanne Becher (Philadelphia: Trinity Press International 1990), p. 93.

\section{BIBLIOGRAPHY}

Qasim Amin (1984), Al-Mar'ah al-Jadidah, Cairo: al-Markaz al-Arabiyah.

Asma Barlas (2005), Cara Quran Membebaskan Perempuan, translated by R. Cecep Lukman. Jakarta: Serambi.

Basisdata dan laporan pelaksanaan BPFA (2007), on http://www.aworc.org/ (accessed on 24 January).

Basisdata dan laporan pelaksanaan CEDAW (2007) on http://www.un.org (accessed on 26 January).

Basisdata dan laporan pelaksanaan MDGs (2007), on http://www.un.org and on www.developmentgoals.org. (accessed on 24 January).

Beberapa Pemikiran Tentang Good Governance, on http://www.goodgovernancebappenas.go.id/ (accessed on 26 July 2007).

Catatan Tahunan tentang Kekerasan Terhadap Perempuan, Komnas Perempuan, 8 March 2006, on http://www.komnasperempuan.or.id/ (accessed on 22 September 2006).

Dzuhayatin, Siti Ruhaini (2002), Pergulatan Pemikiran Feminis dalam Wacana Islam di Indonesia, in Ema Marhumah and Lathiful Khuluq (eds.). 
"Rekonstruksi Metodologis Wacana Kesetaraan Gender dalam Islam," Yogyakarta: Kerjasama PSW IAIN Sunan Kalijaga, Mcgill-ICIHEP and Pustaka Pelajar.

Fakih, M. (1995), Menggeser Konsep Gender dan Transformasi Sosial, Yogyakarta: Pustaka Pelajar.

Florenza, Elisabeth Schussler (1988), In Memory of Her (A Feminist Theological Reconstruction of Christian Origins, London: SCM Press Ltd.

Riffat Hasan (1990), An Islamic Perspective, Women, Religion and Sexuality. Ed. Jeanne Becher. Philadelphia: Trinity Press International.

King, Ursula (1986), Female Identity and The History of Religions, dalam Victor C. Hayes (ed.). "Identity Issues and World Religions." Netley S.A: wakefield Press.

mailing-list "sastra pembebasan" <sastra-pembebasan@yahoogroups.com> [indomarxist] Rusiyati [Dokumen Tercecer]: "Sepintas Gerakan Wanita Indonesia Dalam Perkembangan Sejarah,” (1-5), Thu, 21 Sep 2006 07:31:46 -0700 (PDT); Fri, 22 Sep 2006 03:54:52 -0700 (PDT); Sat, 23 Sep 2006 15:10:49 0700 (PDT); Sun, 24 Sep 2006 16:49:05 -0700 (PDT); Mon, 25 Sep 2006 14:44:29 -0700 (PDT).

Makruf, Sakdiyah. Bukan Semata-mata Tuntutan Perempuan, on http://islamlib.com/, accessed on 16 October 2006.

Manifesto Temu Nasional Aktivis Perempuan Se-Indonesia, 5 September 2006, on http://www.prakarsa-rakyat.org, (accessed on 22 September 2006)

Melani (2006), "Kartini Melawan Kekerasan Dalam Rumah Tangga”, in Pikiran Rakyat, 4 February 2006.

"Membangun Otonomi Daerah bagi Semua," in Kompas, Monday, 16 October 2006.

"MUI Dukung Polri Berantas Pornografi," in Kompas, Tuesday, 26 March 2002.

“MUI Kecam Pornografi di Media Massa," in Kompas, Tuesday, 19 February 2002.

Najib, Mohammad, (2006) "Fatwa Haram Infotainment," in Kedaulatan Rakyat, 26 August 2006.

Pelaksanaan Konvensi CEDAW di Indonesia, Edition II No.3 July-September 2005,

Pengertian Good Governance, on http://www.transparansi.or.id/ (accessed on 29 July 2007)

Pernyataan Pers, Laporan Independen Komnas Perempuan ke Komite CEDAW on 19 July 2007, Mempersoalkan Tanggung Jawab Negara atas Munculnya Kebijakan-kebijakan Diskriminatif bagi Perempuan, on http://www.komnasperempuan. or.id/ accessed on 29 July 2007. 
PSI-UII (2007), Laporan Penelitian dalam program "Sikap Kesetaraan Gender di dalam Keluarga Lintas Agama di DIY".

Rakhmat, Ioanes. Ciri-Ciri Fundamentalisme Kristen Dewasa Ini, in http://www.sttjakarta.ac.id/ (accessed on 22 September 2006).

"Tata Pemerintahan Menunjang Pembangunan Manusia Berkelanjutan" in Buletin Partnership for Governance Reform in Indonesia Volume IV June 12, 2000,

Telaah terhadap feminisme merujuk pada "Feminisme," on http://id.wikipedia.org/wiki/Feminisme. (accessed on 16 October 2006).

Zuhairi Misrawi, 'NU, 'Infotainment,' dan Sikap Moderat" in Kompas, Saturday, 12 August 2006.

Wasim, Alef Theria (1995), "Sosialisasi Wawasan Gender dan Pembangunan", in $A l$ Jami'ah Jurnal Ilmu Pengetahuan Agama Islam No. 581995.

Wirodono, Sunardian (2006), "Fatwa Haram Infotainment, Halalkah?" in Kedaulatan Rakyat, 22 August 2006. 